\title{
Transcription factor-binding sites in the thymidylate synthase gene: predictors of outcome in patients with metastatic colorectal cancer treated with 5-fluorouracil and oxaliplatin?
}

L Paré, E Marcuello, A Altés, E del Rio, L Sedano, A Barnadas and $M$ Baiget
The Pharmacogenomics Journal (2009) 9, 218; doi:10.1038/tpj.2009.17

Correction to: The Pharmacogenomics Journal (2008) 8, 315-320; doi:10.1038/ sj.tpj.6500469; published online 7 August 2007

The authors of this article have noted missing information from the affiliation details. Affiliation \#1 should read as follows:

'Department of Genetics, Hospital de Santa Creu i Sant Pau. Universitat Autonoma de Barcelona. Barcelona, Spain' 